Geosistemy perehodnykh zon = Geosystems of Transition Zones / Геосистемы переходных зон

Content is available under the Creative Commons Attribution 4.0 International License (CC BY 4.0)

2021, vol. 5, No. 2, pp. 167-171

URL: http://journal.imgg.ru/archive.html ; https://elibrary.ru/title about.asp?id=64191

https://doi.org/10.30730/gtrz.2021.5.2.167-171

\title{
Activation of Sarychev Peak Volcano in 2020-2021 (Matua Isl., the Central Kuril Islands)
}

Artem V. DEGTEREV*, https://orcid.org/0000-0001-8291-2289, d a88@mail.ru

Marina V. CHIBISOVA, https://orcid.org/0000-0003-0677-6945, m.chibisova@imgg.ru

Institute of Marine Geology and Geophysics, FEB RAS, Yuzhno-Sakhalinsk, Russia

Abstract PDF ENG Резюме PDF RUS $\quad$ Full text $\underline{\text { PDF RUS }}$

Abstract. This publication, based on remote sensing data, examines the features of the effusive eruption of the Sarychev Peak volcano (Matua Isl., the Central Kuril Islands), which took place from December 2020 till February 2021. On the basis of the analysis of the Sentinel satellite data, it was established that starting from December 2020, the crater of the Sarychev Peak volcano began to fill with lava. As of January 18, 2021, it was completely filled, then lava outpouring through a fissure in the north-northwest part began. A lava flow (length $2 \mathrm{~km}$, width 80-90 m) descended along the bottom of the valley, which cuts the northwestern slope of the volcanic cone. The outpouring of lava was completed by February 7, 2021. The effusive eruption of the Sarychev Peak volcano in 2020-2021 is atypical for the modern stage of eruptive history, characterized mainly by explosive and explosive-effusive type of eruptions.

\section{Keywords:}

The Kuril Islands, the Sarychev Peak volcano, volcano, lava flow, eruption, satellite images, remote sensing data

For citation: Degterev A.V., Chibisova M.V. Activation of Sarychev Peak Volcano in 2020-2021 (Matua Isl., the Central Kuril Islands). Geosistemy perehodnykh zon = Geosystems of Transition Zones, 2021, vol. 5, no. 2, pp. 187-191. (In Russ., abstr. in Engl.). https://doi.org/10.30730/gtrz.2021.5.2.167-171

Для цитирования: Дегтерев А.В., Чибисова М.В. Активизация вулкана Пик Сарычева в 2020-2021 гг. (о. Матуа, Центральные Курильские острова). Геосистемы переходных зон, 2021, т. 5, № 2, с. 187-191. https://doi.org/10.30730/gtrz.2021.5.2.167-171

\section{References}

1. Andreev V.N., Shantser A.E., Khrenov A.P. et al. 1978. [The Sarychev Peak volcano eruption in 1976]. Byulleten' vulkanologicheskikh stantsiy [Bull. of volcanological stations], 55: 35-40. (In Russ.).

2. Gorshkov G.S. 1948. [Sarychev Peak volcano]. Byulleten' vulkanologicheskikh stantsiy [Bull. of volcanological stations], 15: 3-7. (In Russ.).

3. Gorshkov G.S. 1954. [Chronology of Kuril ridge volcanoes eruption]. Trudy Laboratorii vulkanologii [Transactions of the Laboratory of volcanology], 106(8): 58-99. (In Russ.).

4. Gorshkov G.S. 1967. [Volcanism of the Kuril island arc]. Moscow: Nauka, 287 p. (In Russ.). URL: http://repo.kscnet.ru/156/1/Gorshkov 1967.pdf (accessed 04.04.2021).

5. Degterev A.V. 2011. Pyroclastic deposits from Sarychev Peak, Matua Island discharged in June 2009. J. of Volcanology and Seismology, 5(4): 278-285.https://doi.org/10.1134/s0742046311040026

6. Markhinin E.K. 1964. [Sarychev Peak volcano]. Byulleten' vulkanologicheskikh stantsiy [Bull. of volcanological stations], 35: 44-58. (In Russ.).

7. Rybin A.V., Chibisova M.V., Koroteev I.G. 2010. The problems of volcanic activity monitoring on the Kurile Islands. Vestnik DVO RAN = Vestnik of the FEB RAS, 3: 64-72. (In Russ.).

8. Rybin A.V., Degterev A.V., Dudchenko I.P., Guryanov V.B., Romanyuk F.A., Klimantsov I.M. 2017. Comprehensive research on Matua Island in 2017. Geosistemy perehodnykh zon = Geosystems of Transition Zones, (4): 21-29. (In Russ. abstr. in Engl.). doi.org/10.30730/2541-8912.2017.1.4.021-029

9. Chibisova M.V., Degterev A.V. 2019. The activity of Sarychev Peak volcano (Matua Island, Middle Kuriles) in 2017-2018: on the basis satellite and visual data. Geosistemy perehodnykh zon = Geosystems of Transition Zones, 3(1): 144-148. (In Russ., abstr. in Engl.). https://doi.org/10.30730/2541-8912.2019.3.1.144-148

10. Shilov V.N. 1962. [The Sarychev Peak volcano eruption in 1960]. Trudy SakhKNII SO AN SSSR [Transactions of the Sakhalin Complex Scientific Research Institute SB AS of USSR], 12: 143-149. (In Russ.).

11. Rybin A., Chibisova M., Webley P. et al. 2011. Satellite and ground observations of the June 2009 eruption of Sarychev Peak volcano, Matua Island, Central Kuriles. Bull. of Volcanology, 73(4): 40-56. https://doi.org/10.1007/s00445-011-0481-0 